\title{
TO SPEAK AND TO ACT. LANGUAGE AS A MEANS OF PRODUCING SOCIAL CHANGE \\ Oana-Antonia ILIE
}

\section{“Nicolae Bălcescu” Land Forces Academy, Sibiu, antoniailie@yahoo.com}

\begin{abstract}
The performativity theory starts from a critique of the descriptivist and representation a list theory of language, thus, language and word use cease to appear as mere modalities of describing the world and our connection with the environment, and become a manner of acting and of producing action. Prefigured in the Theory of Communicative Action of J.L. Austin, further analyzed by J. R. Searle and other pragmatists, the illocutionary speech acts make the distinction between the content of an expression and the action that we undertake through it. Their transformation in action is a transition from the assertion plan to the realization plan, through the explicit performative utterances ("I order you to", "I ask you to", "I solicit that you").
\end{abstract}

Keywords: speech acts, performative verbs, locution, illocution, perlocution, communicative action

1. From language to action. The (naming, ordering, promising, instituting). performative speech acts Austin, in his "How to do things with Although there are concerns and reflections on language as a means of determining action long before the appearance of a unified theory, the Theory of Speech Acts founded by John Langshaw Austin is the first free-standing theory that captures the actional dimension of language, and thus occupying a central place in the pragmatics of communication. The research of Austin, continued by his disciple John Searle (and other pragmaticiens) bring forward the hypothesis of language functioning as a set of speech acts, the "speech acts" being considered the fundamental elements of speech that must be understood within the speech communities to which they belong. Both Austin and Searle point out that language has not only the function of saying, but also that of producing change. Their work deals in principle with the performative verbs that have as a characteristic feature the aspect that they perform an action by their mere uttering words" book, signals, in addition to the locutionary side of the language (what is said), an illocutionary side responsible for determining action. Such speech acts appear in contrast with the observation statements: A.they do not describe or report or constate anything at all, are not true or false.

$B$. the uttering of the sentence is, or is a part of, the doing of an action, which again would not normally be described as saying something. [1]

Transforming these acts into action is made through the transition from the assertion plan to the achievement plan, by explicit performative expressions of the form "I order you to", ,, can you please", "I warn you that". The examples that the author gives are the following:

I do - as uttered in the course of the marriage ceremony

I name this ship the Queen Elizabeth, as uttered when smashing the bottle against the stem 
I give and bequeath my watch to my brother-as occurring in a will

I bet you six pence it will rain tomorrow [2]

Austin names five categories of illocutory tenses:

1. Veridictive (to describe, to postulate)

2. Exercitives (to order, to demonstrate)

3. Commissives (to promise, to consent)

4. Behavitives (to excuse oneself, to apologise)

5. Expositives (to affirm, to baptize) [3]

According to Austin, speech acts consist of three components:

1. A locutionary component (through which meaning is achieved)

2. A illocutionary component (expressing a certain intention)

3. A perlocutionary component (achieving a particular effect on the receptor)

Thus, assertions appear as processes comprising three categories of acts:

- the locutory act (the constative saying as such)

- the ilocutory act (act that says what to do)

- the perlocutory act (act performed by saying something) [4].

The further development of pragmatics highlights the reconstruction of the speech acts theory by John Searle, disciple and follower of Austin. A special role is played in this theory by the act of promise, Searle's intention being to formulate a system of conditions for the fulfillment of this speech act, conditions that can be applied to all illocutionary acts. [5] Searle further analyzed the explicit and implicit illocutionary acts. Explicit performatives are expressed by verbs usually in the first person singular, present indicative, active voice, and designate actions (examples: $I$ affirm, I order, I command) and appear associated with the idea of imperative, and implicit performatives are constructions that can replace or be brought to this form. Some examples are:

1. explicit performative acts: "Now I pronounce you husband and wife", "I order you to leave", "I Christian you ", , "I sentence you to prison", "I divorce you "'II promise / swear", "I dedicate this", "I promise to be there", "I dedicate this", "I declare War", "I quit"

2. implicit performative acts and constructions: "Apology accepted", "You're under arrest", "This court is adjourned" „You can not smoke here,, "Would you mind if $I$ asked you (to do something)", "You may (do something) "It is forbidden (to do something)"

The theory of speech acts operates a fundamental separation with the traditional linguistic analysis of statements and claims that among speakers' statements, there are statements other than those descriptive that are not true or false and which are subject to felicity conditions, depending on their success / failure.

\section{Felicity conditions of the performatives}

Austin asserts that when the enterprised action is not successful we cannot declare the assertion as false but as unhappy. These failures of the speech acts are called by the author infelicities, divided into misfires or abuses. He also gives a few rules for the success of such speech acts:

A1) There must be a conventional procedure having a conventional effect

A2) The particular persons and circumstances in a given case must be appropriate for the invocation of the particular procedure invoked

B1) The procedure must be executed by all participants both correctly and

B2) completely

T1) Where, as often, the procedure is designed for use of persons having certain thoughts or feelings, or for the inauguration of certain consequential conduct on the part of any participant, then a person participating in and so invoking the procedure must in fact have those thoughts or feelings, and the participants must intend so to conduct themselves and further

T2) must actually so conduct themselves subsequently [6]

Searle argues that performatives can be true or false just like the constatives. Performative statements would be true if 
successful, managing to make propositional content true. The conditions for the success of such acts play a more or less decisive role in their performance. Not everyone and in every circumstance is authorized to assert, to order, to establish, to appoint, to suspend, etc. It is necessary that the speaker, when uttering such statement, possesses a certain credibility and sufficient authority, obeying a law and the requirements of an official position. Outside the circumstances that make them performative, such statements do not mean anything. [7]

Searle and Vandervecken in the Foundations of Illocutionary logic indicate seven components that determine the conditions of success and satisfaction of these speech acts:

1. The purpose of the illocutionary act

2. The power of the purpose of the illocutionary act

3. The method of implementation (eg, greater authority gives greater force to achieve especially if we talk about measures such as orders)

4. The propositional content condition (conditions of achievement $F(P)$ ) 5. The preparatory condition (preparatory assumptions fulfillment)

6. The sincerity condition (mental state that must have who performs)

7. The power of sincerity condition (force that mental states) [8]

For Grice, social communication, beyond the actual transmission of meaning is a tacit recognition of intentions, performative action becomming possible when a communicator recognizes the intentions behind the act. Grice distinguishes between indicative statements ( $\mathrm{E}$ wants $\mathrm{R}$ to believe something) and the imperative statements (E wants $\mathrm{R}$ to do something) that meet under the concept of propositional attitude (I think $p$, I believe $p$, I want that $p$ ) Forming of propositional attitudes by indicative utterances means $\mathrm{E}$ 's intention that $\mathrm{R}$ understands that he believes something, and its formation through imperative statements means that $\mathrm{E}$ wants to determine $\mathrm{R}$ to do something. Strawson and Schiffer distinguish three subintentions:

1. As T's statement $X$ to produce a response $R$ from the audience $A$

2. As $A$ to recognize $T$ 's intention

3. As the recognition of T's intention to be at least a part of the reason why A produces the answer [8]

The institutional context, position, status, degree of authority must be appropriate to this type of act of communication. In any case, a performative utterance has no reality unless it is an authenticated act.

\section{Conventions of performativity}

The performativity theory requires a social framework, involves communication rules, even institutions (an institutional framework is often required) and the concept of communication contract. Performativity may involve legal acts (laws, ordinances, resolutions, regulations) and is characterized by a genuine power over the real, even that of creating the real, being the force behind social development and change. They can express / perform an engagement, an intent, a promise, a decision, an interdiction, etc. Some explicit performative expressions have both performative and illocutionary descriptive content, others (such as "thank you" excuse me) lack descriptive content and appear in pure form. Austin defines a number of other acts, the "perlocutionary acts" speech acts characterized by the certainty that the speaker has accomplished the targeted action. He argues that all statements are dependent of the illocutionary acts, more, he notes the continuous presence of a illocutionary side in any speech act, given the many forms that illocution is met ( $I$ foresee that you will be elected, I sustain that you will be promoted). The performativity theory insists upon the importance of the social convention as the background of all successful speech acts. Conventions violation make impossible the fulfillment of the illocutionary acts, leading to communication dysfunctions. 
Jean Lohisse, developing on the ideas of Austin, states that the success of the performative speech acts depends on three categories of conditions:

1. linguistic (certain formulas are preferable to others

2. sociologic ( the speaker must have a certain authority or status)
3. psychological (a inner disposition for the engagement) [9]

A performative message is well formulated if it will arouse the motivation necessary to perform the action. The specialist in Public Relations knows how to formulate such messages that can induce feelings of compassion or indignation and mobilize the masses to take action.

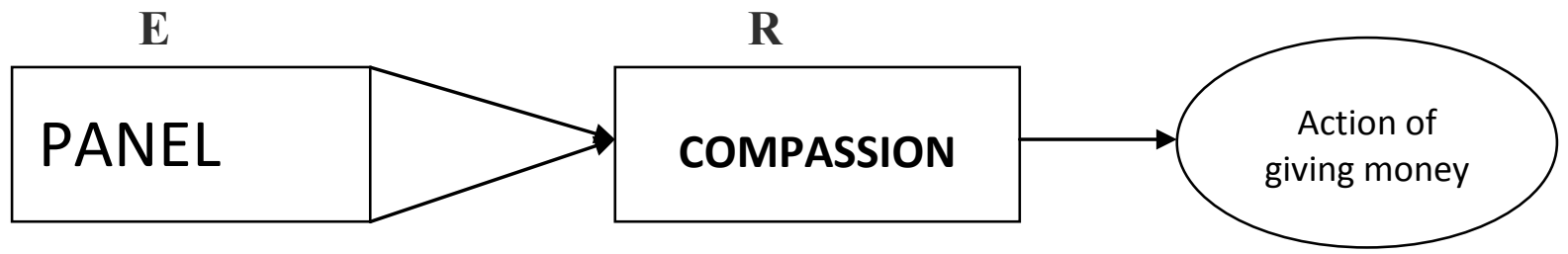

Figure 1: The persuasion model presented above resembles the classical Emitter -Receiver communication model and is based on the following scientific postulates:

1. the content of the message has a certain force (effect)

2. change in message (content) results in change of action

3. the effect on the behavior is connected with the content of the message

4. the content acts over a psychological predisposition (motivation, need, force).

5. the psychological mechanism finally results in action [10]

\section{Further developments}

The performativity theory of Austin and Searle that discusses the concepts of ilocutory and perlocutory speech acts represent a turning point in language theory, envisaging the connection between language and reality and showing the instances where language and reality actually collapse into "deed". The theory, together with Max Weber's concept of social action and other constructivist sociology considerationsare the basis of Habermas's theory of communicative action. Performative acts and communicative action play an important role in building a common world by targeting a variety of actions, strategies, practices and institutional aims. The communicative action model of Habermas, (identified with the ilocutory acts) is defined as a non-teleological search of a common definition of the circumstances, a rational agreement regarding the meaning and the strategic action model (identified with the perlocutory acts) is seen as a teleological, interest oriented model, representing social actions.Knowing the force that language has over the real, its power to produce social change, we must not ignorethe fact that controlling this force could have a benefic role in social development, by creating and directing certain social flows in the direction of positive, humanitarian causes.

\section{References}

[1] [2] Austin, J.L., Cum să faci lucruri cu vorbe, Editura Paralela 45, București, 2003, p. 27

[3] ibid, p. 134-137

[4] Drăgan, I., Comunicarea, paradigme și teorii, vol.I, Rao International Publishing Company, București, 2007, p. 269

[5] Searle, J. How Performatives work, Linguistics and Philosophy, 12(5), p. 535-558, 1989

[6] Austin, J.L., Cum să faci lucruri cu vorbe, Editura Paralela 45, București, 2003 
[7] Searle, J., Vandervecken, D., Foundations of Illocutionary Logic, Cambridge University Press, 1985

[8] Drăgan,I., Comunicarea, paradigme și teorii, vol.I, Rao International Publishing Company, București, 2007, p. 169

[9] Drăgan, I., Comunicarea, paradigme si teorii, vol. I, Rao International Publishing Company, București, 2007, p. 536

[10] Muchielli, A., Arta de a influența. Analiza tehnicilor de manipulare, Editura Polirom, București, 2002, p 38 